\title{
Analysis of Morphometric Changes in Tondano Lake Based on Bathymetric Maps
}

\author{
Helena Sri Sulastriningsih ${ }^{1}{ }^{*}, J C$ Kumaat $^{1}$, Murnisulistyaningsih ${ }^{2}$ \\ ${ }^{1}$ Geography Study Program, Faculty of Social Sciences, Manado State University, North Sulawesi \\ ${ }^{2}$ Mathematics Study Program, Faculty of Natural Sciences, Manado State University, North Sulawesi
}

\begin{abstract}
This study aims to analyze changes in the morphometry of the lake bottom in a period of ten years, namely from 2006 to 2016 . The analysis of morphometric changes is carried out by comparing two bathymetric maps from the mapping in 2006 and 2016. The morphometric aspects studied include the water surface area stated in $\mathrm{km}^{2}$, the volume of water $\left(\mathrm{in}^{3}\right.$ ) and the depth of the lake (in $\mathrm{m}$ ). The results showed that within 10 years the surface of the lake water has decreased by $1.03 \mathrm{~km}^{2}$, while the total volume of lake water has increased by $10.41 \mathrm{~m}^{3}$. The average depth of the lake in a period of 10 years has barely changed significantly, only silting of about 0.01 meters. Judging from the contour pattern, it shows that there is a tendency for siltation to move not only towards the south but also towards the east. That means more sediment contributions come from the western region. The rain catchment area on the west side of the lake has a larger area when compared to the east side (Eris District). The sediment potential is greater from this area.
\end{abstract}

Keywords: Bathymetry, Morphometry, Map

\section{Introduction}

Allegations of factors causing the silting of Tondano lake are still being debated by various groups, including academics, researchers, non-governmental organizations and journalists. Even policy makers often make statements regarding the silting of Tondano Lake. This means that the public's concern and concern for the silting of Tondano lake which has strategic and importance for the North Sulawesi region is still very high. Despite differences of opinion, Tondano lake has been designated by the State Ministry of the Environment (2011) to be one of the 15 lakes in Indonesia that has priority for rescue.

The deepest depth of Tondano lake as a result of measurements made by the Dutch in 1898 was 28 meters which was found in the southern part, and in the northern part it was 15 meters deep (Koperberg, 1928) in reference [1]. Another source quoted by BRLKT (1992) stated that the depth of Tondano lake in 1934 was recorded at 40 meters, in 1983 the deepest depth was 27 meters, while in 1988 it was 20 meters, and last year in 1992 it was reported that it was only 16 meters. Other information mentions the depth of the lake in 1939 was estimated at 43 meters and became about 19 meters in 1992 [2]. Hikmatullah, et.al., (2000) in his research reported the depth of the deepest lake at that time was 22 meters.

In contrast to the research report conducted by Samratulangi University in 2000, the lake depth was 14 meters (Ministry of the Environment, 2011) [3], while the Manado State University Research Institute (2006) found the highest lake depth was 23 meters. The bathymetry map measured in May 2010 sourced from the WIIP Bathymetry Survey (Makmur, et al., 2015) informs that the depth of the deepest lake ranges from 22 to 34 meters. In the same year, the Director General of Natural Resources-BWS reported that the average depth of Tondano lake was 15.11 meters with an inundation area of $46.16 \mathrm{~km}^{2}$ and a capacity of 668.57 million $\mathrm{m}^{3}$ (Ministry of the Environment of the Republic of Indonesia, 2014) [3]. Meanwhile, a hydroacoustic survey conducted by the Ministry of Maritime Affairs and Fisheries (2016) in March 2016 stated that the highest lake depth reached 30 meters.

Observing the data above, it raises the question, was it true that there was a decrease in the bottom of the lake from 28 meters in 1898 to 40 meters in 1934, and then an increase in the bottom of the lake to 27 meters in 1983. To discuss the reality of the data, it can be done through a methodological approach, geological and geomorphological, however, is not a concern in this paper. This study emphasizes the description of changes

\footnotetext{
*Corresponding author : hs_sulastri@unima.ac.id
} 
in the morphometry of the lake bottom and analysis of the tendency of sediment load sources that have the potential to contribute to lake silting based on a series of bathymetric maps.

Lake morphometry is the shape of a lake's water body which includes the surface area of the lake water, the volume of water, and the average depth [4]. Information on morphometry is needed to get a picture of the physical condition of lake waters both vertically (subsurface dimensions) and horizontally (surface dimensions) [5]. Surface dimensions include the length and width of the lake, the surface area of the lake water, while the subsurface dimensions include the depth of the lake and the volume of lake water [6]. Lake morphometry is strongly influenced by environmental variables such as sedimentation processes, therefore morphometric data can be used to evaluate sediment accumulation and scattering patterns [7].

The source of the sediment load that enters the bottom of the lake is also an interesting issue discussed by various parties with an interest in Tondano lake. There are at least two different poles in addressing the source of the charge that enters the bottom of the lake. The first party stated that the main source of sediment load came from erosion on dry land in the upstream, but also not a few who argued that the source of sediment load came from activities that occurred in the lake waters and from processing wetlands around the lake.

This statement is used as a basis by both parties in addressing the age of the lake. The head of Minahasa Regency Regional Development Agency (Bappeda) (2007) estimates Tondano Lake will only last for the next 40 years or around 2047. Previously, BRLKT (1992) predicted that Tondano lake would only last until 2020 , and in fact this prediction is very far from reality. Another assumption was made by Hikmatullah, et.al. (2000), which states that the amount of sediment that enters the lake is 7,540 $t$ /year when compared to the lake volume of 680 million $\mathrm{m} 3$, then the lake will be filled with sediment in a period of thousands of years.

Starting from the disagreements regarding the depth of the lake, the source of sediment loading that enters the lake bottom, and the age of the existence of Tondano Lake in the future, this study is intended to examine changes in the morphometry of the lake floor based on a series of bathymetric maps.

\section{Materials and Methods}

This research was conducted in Tondano lake, Minahasa Regency, North Sulawesi using bathymetry data for 2006 and 2016. Both maps were digitized using ArcView 3.3 software for the analysis of the morphometric aspects needed in this study. The morphometric aspects observed in this study are the surface area of the lake water $\left(\mathrm{m}^{2}\right)$, the average depth $(\mathrm{m})$, and the total volume of lake water. The surface area is expressed in $\mathrm{m} 2$ which is the surface area of the lake water, which is measured based on the polygon area on the bathymetric map with the help of GIS. The average depth of the lake is calculated by dividing the total volume of lake water by the water surface area expressed in meters. The total volume of lake water is calculated by multiplying the surface area $\left(\mathrm{m}^{2}\right)$ with the average depth $(\mathrm{m})$ in each contour layer. Analysis of changes in lake morphometry was carried out by comparing the lake morphometry in 2006 and 2016.

This research was conducted in Tondano lake, Minahasa Regency, North Sulawesi using bathymetry data for 2006 and 2016. Both maps were digitized using ArcView 3.3 software for the analysis of the morphometric aspects needed in this study. The morphometric aspects observed in this study are the surface area of the lake water $\left(\mathrm{m}^{2}\right)$, the average depth $(\mathrm{m})$, and the total volume of lake water. The surface area is expressed in $\mathrm{m} 2$ which is the surface area of the lake water, which is measured based on the polygon area on the bathymetric map with the help of GIS. The average depth of the lake is calculated by dividing the total volume of lake water by the water surface area expressed in meters. The total volume of lake water is calculated by multiplying the surface area $\left(\mathrm{m}^{2}\right)$ with the average depth $(\mathrm{m})$ in each contour layer. Analysis of changes in lake morphometry was carried out by comparing the lake morphometry in 2006 and 2016.

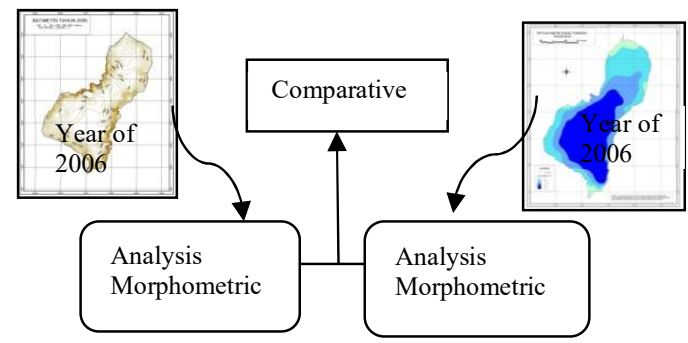

Fig.1. lake morphometry in 2006 and 2016

\section{Result and Discuss}

The results of the analysis show that during the period 2006 to 2016 there was no significant change in the morphometry of Tondano lake. The morphometric dimension changes successively are described in the following explanation

\subsection{Changes in Lake Water Surface Area The lake}

Water surface area is calculated at every 5 meters contour interval, starting from the 0 meter contour interval to the deepest contour interval, which is the 20 meter contour interval.

The water surface area is the area of the polygon on each contour interval. Each polygon is calculated using the $X$ tools extension available in the ArcView GIS software. The results of the analysis of the water surface area are presented in the table 1 . 
Table 1. Comparison of Water Surface Area by Lake Depth (in $\mathrm{km}^{2}$ )

\begin{tabular}{llll}
\hline $\begin{array}{l}\text { Depth } \\
\text { (Meters) }\end{array}$ & $\begin{array}{c}\text { Years } \\
\mathbf{2 0 0 6}\end{array}$ & $\begin{array}{r}\text { Year } \\
\mathbf{2 0 1 6}\end{array}$ & Change \\
\hline 0 & 46,91 & 45,88 & $-1,03$ \\
5 & 39,34 & 43,78 & 4,44 \\
10 & 30,76 & 30,65 & $-0,11$ \\
15 & 20,00 & 19,33 & $-0,68$ \\
20 & 0,52 & 0,15 & $-0,37$ \\
\hline
\end{tabular}

Results of bathymetry map analysis (2018)



Fig.2. Comparison of lake water surface area in 2006 and 2016 by depth

The table above shows that the lake's water level has not experienced a significant change over a period of 10 years. The surface of the lake water at a depth of 0 meters has decreased, but on the contrary at a depth of 5 meters there is an increase in the surface area of the lake water. These data indicate that there has been a process of silting of the lake, and conversely at a depth of 5 meters it can be assumed that abrasion occurs so that the water surface area at that depth increases.

The results of the above analysis support the previous research conducted by Trisakti and Nugroho (2012) using multi-temporal satellite imagery from 1990 - 2011 which results in the shape and surface area of Tondano lake being relatively unchanged, with an area of $46-47 \mathrm{~km}^{2}$. The results showed that there was a narrowing of the lake water surface area of $-1.03 \mathrm{~km}^{2}$.

\subsection{The total volume of the lake water}

the total volume of the lake as a whole has increased from 364.11 million $\mathrm{m}^{3}$ in 2006 to 374.53 million $\mathrm{m}^{3}$ in 2016. The increase in the volume of water in the lake at 10.41 million $\mathrm{m}^{3}$ occurred in the past 10 years. The largest volume change occurs at a depth of 0-5 meters, which is 10.05 million $\mathrm{m}^{3}$. There is a match between the increase in the lake water surface zone and the total volume of water in each depth zone. The increase was due to changes in the morphology of the lake bottom as a result of sedimentation.
Table 2. Change in Volume According Lakes Water Depth Zone (million m3)

\begin{tabular}{llll}
\hline Zone Depth (m) & $\mathbf{2 0 0 6}$ & $\mathbf{2 0 1 6}$ & Change \\
\hline 145.27155 .32120 .40 & & & 10.05 \\
$5-10$ & 116.25 & $0-5$ & 4.15 \\
$10-15$ & 80.78 & 78.95 & -1.83 \\
$15-20$ & 21.30 & 19.70 & -1.60 \\
$>20$ & 0.52 & 0.15 & -0.37 \\
\hline Total & 364.11 & 374.53 & 10.41 \\
\hline
\end{tabular}

Bathymetric map analysis results, (2018)

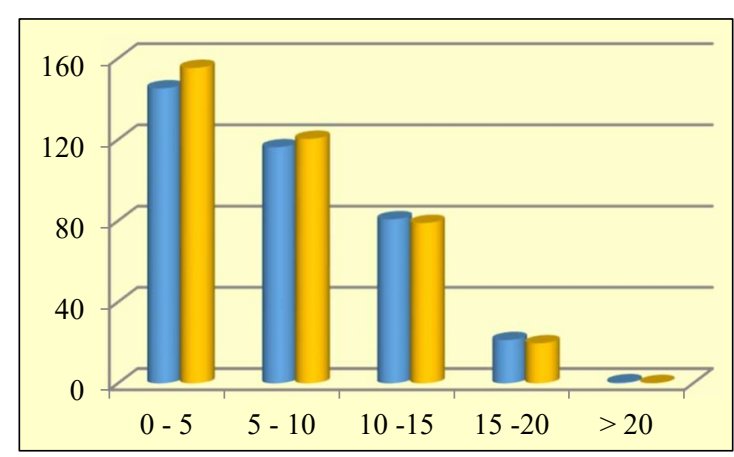

Year of 2006 Year of 2016

Fig.3. Comparison of lake water volume $\left(\right.$ million $\left.\mathrm{m}^{3}\right)$ in 2006 and 2016

\subsection{Average depth of Tondano lake}

The average depth of a lake is the relationship between water volume and water surface area. The results of the analysis of the average depth of the lake based on the 2006 and 2016 bathymetric maps are presented in Table 3.

Table 3. The average depth of the lake According Zone Depth (in meters)

\begin{tabular}{|c|r|r|r|}
\hline Depth & 2006 & \multicolumn{1}{c|}{ 2016 } & Change \\
\hline $0-5$ & 3,10 & 3,39 & 0,29 \\
\hline $5-10$ & 2,95 & 2,75 & $-0,20$ \\
\hline $10-15$ & 2,63 & 2,58 & $-0,05$ \\
\hline $15-20$ & 1,06 & 1,02 & $-0,04$ \\
\hline$>20$ & 1,00 & 1,00 & 0,00 \\
\hline Total & 10,74 & 10,73 & $-0,01$ \\
\hline
\end{tabular}


Result of bathymetric map analysis (2018)

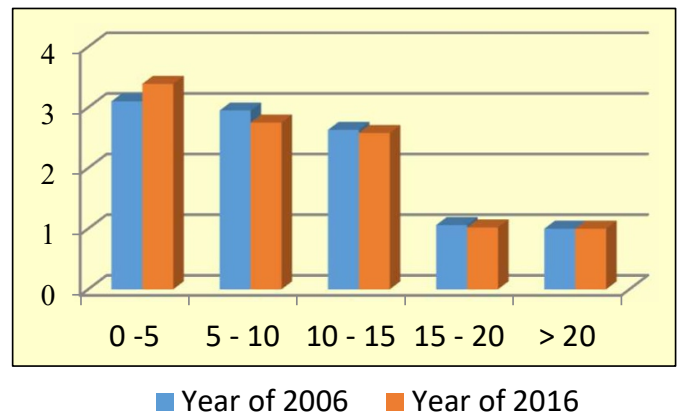

Fig.4. The average depth of the lake According Zone Depth in 2006 and 2016

Based on the table above, the average depth of Tondano Lake does not experience drastic changes. The average total depth of the lake in a span of 10 years is only about 0.01 meters. If it is assumed that the average decrease in lake depth is only about $1 \mathrm{~cm}$, within 10 years, Tondano lake will disappear from the earth's surface in thousands of years. The results of this analysis are in accordance with research conducted by Hikmatullah, et. al (2000) which states that Tondano Lake will be completely filled in thousands of years.

\subsection{Analysis of Morphometric Changes}

The morphometric aspects observed in this study were the surface area of the lake water, the volume of the lake water and the average depth of the lake. These three aspects are related to the sedimentation process. The area of the lake water table can be used to predict whether there is a sedimentation process beneath it. However, the water surface area is not the only parameter that can be used to detect the source of the sediment load.

The analysis showed the water surface area shrinks the lake area of $1.03 \mathrm{~km}^{2}$ within a period of ten years. This information illustrates that there is no change in the surface area of the lake water. The increase in sediment load that drives the expansion of the water surface of Tondano Lake still needs to be studied further.

The surface area of lake water is closely related to the volume of lake water. The analysis showed an increase in the volume of water in the lake at 10.41 million $\mathrm{m}^{3}$ within a period of 10 years at a depth of $0-5$ meters. This increase occurred due to an increase in the water surface area at a depth of 5 meters. The volume of lake water also gives an idea of the size of the lake's capacity and at the same time can be used to predict the age of the lake. One of the factors that causes a decrease in the capacity of the lake is the occurrence of sedimentation to the bottom of the lake.

The depth of the lake also determines the capacity of the lake. The faster the lake is silting up, the faster the lake depth will decrease. The results showed that the average depth of the lake for 10 years experienced a very small decrease, which was 0.01 meters. This data illustrates that the silting process that occurs in Tondano lake is very small, so the assumption that silting in Tondano Lake is very worrying is too much.

The results of the bathymetric map analysis show that there has been no significant change in the depth of the lake bottom in the last 10 years as predicted by previous researchers who stated the process of silting the lake by 0.43 meters per year. Based on these assumptions, and if the factors causing siltation are in the same condition; then the deepest lake bottom depth in 2006 should be around 13 meters. In fact, the results of the 2016 bathymetry map analysis show other data, namely the depth of the lake bottom is still in the range of 20-22 meters. It is recognized that the prediction of erosion rates made by previous researchers was only based on indirect estimates, namely by using the USLE (Universal Soil Loss Equations) method which is commonly used to predict sheet erosion. On the other hand, not all erosion in the upstream part will be entirely deposited on the lake bottom, but partly retained by land cover and basins, both natural and man-made.

\section{Conclusion}

There is no significant change in lake morphometry. The surface area of the lake water has decreased by $1.03 \mathrm{~km}^{2}$ or $0.01 \mathrm{~km}^{2} /$ year and changes in the depth of the lake bed have barely occurred in that period. Lake water volume changes occur at a depth of 0-5 meters is one million $\mathrm{m}^{3} /$ year. It turned out that the water level of the lake at a depth of 5 meters is also increasing an area of $4.4 \mathrm{~km}^{2 / 10}$ years. These morphometric changes indicate that the silting of Tondano lake is not as fast as predicted by several previous studies. It can be stated that the erosion rate in the Catchment Area of the Tondano watershed is well controlled. This study also strengthens JICA's (2001) study which stated that during 1994 2000 there was no sedimentation at the bottom of Tondano Lake.

\section{References}

[1] Hikmatullah, H. Subagyo, U. Kurnia, and L. I. Amien, 'Evaluation of Erosion and Siltation of Lake Tondano Based on the Hydrological and Soil Characteristics of Its Catchment', Indones. Soil Clim. J., vol. 18, no. 2, 2012.

[2] F. B. Saroinsong, 'Supporting plant diversity and conservation through landscape planning: A case study in an agro-tourism landscape in Tampusu, North Sulawesi, Indonesia', Biodiversitas J. Biol. Divers., vol. 21, no. 4, 2020.

[3] H. D. Walangitan, B. Setiawan, B. Tri Raharjo, and B. Polii, 'Optimization of land use and allocation to ensure sustainable agriculture in the Catchment Area of Lake Tondano, Minahasa, North Sulawesi, Indonesia', Int $J$ Civ Env. Eng IJCEE-IJENS, vol. 12, no. 3, pp. 68-75, 2012.

[4] O. T. Rämö, R. Dall’Agnol, M. J. B. Macambira, A. A. S. Leite, and D. C. de Oliveira, '1.88 Ga oxidized A-type granites of 
the Rio Maria region, eastern Amazonian craton, Brazil: positively anorogenic!', $J$. Geol., vol. 110, no. 5, pp. 603-610, 2002.

[5] R. Ridoan, A. Muhtadi, and P. Patana, 'Morfometri Danau Kelapa Gading Kota Kisaran, Kabupaten Asahan Provinsi Sumatera Utara', DEPIK J. Ilmu-Ilmu Perairan, Pesisir dan Perikan., vol. 5, no. 2, 2016.

[6] Z. Agnesia, D., Bakti, D., Harahap, 'Hydromorphological Study of Lake Martubung Indah, Medan Labuhan District, North Sumatra', J. Aquacoastmarine, vol. 15, no. 1, 2017.

[7] M. S. Da Silva, J. T. F. Guimarães, P. W. M., and S. Filho, 'Morphology and morphometry of upland lakes over lateritic crust, Serra dos Carajás, southeastern Amazon region', J. An. da Acad. Bras. Ciências, vol. 90, no. 2, 2018. 